\title{
Spider Woman
}

$\mathrm{R}$ estoration is so broad a topic, and touches so many aspects of life and thought that I find myself picking up useful connections in all sorts of unlikely places.

Take, for example, "Sister Wendy's Story of Painting," the recent PBS series in which an English nun guides viewers on a personal tour of some of the great works of Western art. In the segment on the Renaissance, Sr. Wendy pauses before Titian's late masterpiece "The Flaying of Marsyas" to offer some reflections on the business of defying the gods that seem to me to bear directly on the work of the restorationist.

Marsyas, Sr. Wendy explains, was a mortal in Greek myth who, being adept at playing the flute, and overconfident of his abilities, challenged Apollo, god of music, to a contest of fluteplaying. The agreement was that the winner could do as he liked with the loser, and when Apollo won, he chose to have Marsyas flayed alive.

The spectacle of the flaying of Marsyas seems to have been a popular one among Renaissance artists, and it provided plenty of scope for visual spectacle. Titian's portrayal is shocking-a butcher-shop scene, rendered in violent strokes of red and yellow, made all the more horrifying by its pastoral, wooded setting. ( $\mathrm{Cu}-$ riously, this painting does not appear in the book version of Sr. Wendy's series, which includes a different painting depicting the same myth.)

This is not the sort of picture you would want to hang in your living room. But it is not the manifest violence and pain of this scene that attracts Sr. Wendy's attention, but something else, suggested by the expression of Marsyas, that lies beyond pain.

"Marsyas's eyes are bright," she notes. "His arms are surrendered. Even though a little dog laps his blood, Marsyas is ecstatic because he knows that this is proof that he has gone the whole way ..." in stripping himself bare, in challenging the god, in carrying out the work of the artist, the world-creator.

Here, then, even in the midst of the pain and calamity that is the inevitable result of challenging the gods at their work, the Renaissance artist hints at a deeper satisfaction. The god, he suggests can be defied - indeed, he must be defied. It is our business to defy the gods, whatever the cost, and, despite the costs, this is the way to the profoundest satisfaction.

Intrigued, I called Herb Howe, an emeritus professor of classics at the UW-Madison, who made the translations for the recently published Classical Myth by Barry Powell. Howe told me that the perils and consequences of defying the gods is a central theme of the Greek myths, and in fact can be found in virtually all of the theological myths-that is, the ones that deal with the Olympian gods.

This, after all, is the human dilemma-and it is one the restorationist faces in an especially dramatic way. Making a prairie or a wetland-playing god, some have called it-what presumption! What arrogance! What wicked conceit!

Yes-and how inevitable. How dangerous. How shameful, and-in the end-how beautiful.

One after another the Greek myths reaffirm this point- the repayment of presumption by pain - and also by fulfillment and beauty.

Consider the story of the Titan Prometheus, for example. Prometheus is famous for stealing fire from the gods and bringing it to humans, placing in their hands the power of technologyof world-making. Less well known is an earlier adventure in which, attending a banquet of the gods, Prometheus tricked Zeus, offering him the bones of the sacrificed animal temptingly disguised as the choicest part. In this way, Prometheus taught humans the crucial lesson-perhaps the core of culture-that even the greatest of the gods can be fooled-as they must be in the exchange of gifts, since humans can never make perfect reparation, can never give back all they owe to the gods.

For both offenses Prometheus was punished. But here again the story offers a promise of redemption, as in the end Zeus, indebted to Prometheus for a favor, grudgingly allows Heracles to free him.

The gods, the story suggests, need us. And though in their pride and wilfulness they punish us for our presumption, there is a higher law beyond even the gods that ensures that in the end we are rewarded and the world is made more beautiful as a result of our efforts.

Take another myth of pride and presumption that seems to speak directly to the restorationist in his or her work of worldmaking - that of Arachne the weaver. Like Marsyas, Arachne presumed to defy a god-not only challenging Athena to a contest in weaving, but unwittingly insulting her in the process. But unlike Marsyas, Arachne does not lose. Her weaving is the match of Athena's so that, in Prof. Howe's translation from Ovid's Metamorphoses (5:129), "... Not Pallas (Athena), not envy itself, could find a fault in the weaving."

This, of course, is an affront far more serious than that of losing. Enraged, Athena strikes Arachne who, in fright, hangs 
herself, and then-bringing in the note of universal compassion-Athena takes pity on her, rescues her, and transforms her into a spider.

Messages for the restorationist abound in these stories. There is a risk in presuming to take on the work of the gods (we might substitute Nature), but also an ultimate reward. Arrogance and insolence will be punished mercilessly—as will success. But pluck and skill will be strangely rewarded. We need not (as we cannot) give back all we owe, which is troubling. But in the end the debt is forgiven. The gods relent, or at least, like Zeus, look the other way. Vengeance is mitigated. Prometheus is freed from the rock. And Arachne's fate, though frightening, is perhaps also the ideal of the restorationist - to become a member of the community of life itself, weaving the world.

William R. Jordan III 